\title{
TATIANA SEDOVÁ, ZUZANA PALOVIČOVÁ: Zdravotné postihnutie v kontexte l'udských práv. Filozofická reflexia
}

Bratislava: Veda 2018, 143 s.

Otázka idey l’udských práv v kontexte zdravotného postihnutia je v súčasnosti reflektovaná z rôznych perspektív - právnej, sociologickej, politologickej či historickej. Autorky v publikácii ponúkajú filozofické aspekty tejto problematiky, pričom vychádzajú z predpokladu, že v tomto interdisciplinárnom skúmaní má filozofia skôr mediačnú úlohu. Podl'a nich filozofický prístup umožňuje odlíšit' historické aspekty l'udských práv spojených s konkrétnymi mocensko-právnymi konšteláciami od systematickej otázky ich zdôvodnenia, zdrojov, adresátov, vzt’ahu k právnym nárokom a povinnostiam až k záväzkom, morálke a spravodlivosti. Analýza problematiky filozofickými metódami im umožňuje preskúmat' konceptuálne a argumentačné problémy, akými sú napríklad normatívnost' l'udských práv, obsah pojmu l'udskej dôstojnosti ako ústredného pojmu l’udských práv, vzt’ahu l’udských práv a pojmov človek, osoba, autonómia (s. 27 - 28). Osobitne možno ocenit' tento prístup, pretože jeho konzekvencie sa netýkajú len filozofických zdôvodnení l'udských práv, ale sú istým základom aj pre praktické úvahy o tom, čo by sa malo realizovat' v rámci uplatňovania l'udských práv v slovenskom prostredí. V tomto zmysle má práca filozofický aj praktický význam.

Publikácia nadväzuje na predchádzajúce skúmanie autoriek, najmä z oblastí sociálnej a politickej filozofie. Práca je rozdelená do šiestich tematicky a logicky na seba nadväzujúcich kapitol. V prvej autorky filozofickým štýlom a teoreticko-metodologickým postupom analyzujú mnohotvárny a zložitý, ba až protirečivý vzt'ah empirických a sociálnych vied v súvislosti s ekonomickou a kultúrnou globalizáciou a presadzovaním idey l'udských práv. Na základe neho ukazujú, že sa vynára staronový problém vzt’ahu medzi prírodou a kultúrou (resp. spoločnost’ou), medzi mocou a poznaním, svetom vecí, artefaktov a l'udí, medzi hodnotami a faktami, vedeckým poznaním, technológiou a politikou (s. 12). Teoreticko-metodologické východisko umožňuje autorkám problematizovat' pozíciu človeka so zdravotným postihnutím v sociálnom a prirodzenom kontexte, čím predkladajú odvážnu tézu, že idey európskeho občianstva zoči-voči realitám životného sveta Európanov ostávajú neživými abstrakciami (s. 14). S týmto tvrdením možno do istej miery súhlasit', pretože individuálna identita (napr. presadzovanie práva na inakost' a vlastný životný štýl) zdôrazňuje skôr konkrétne individuálne zdravotné postihnutie konkrétnej osoby, zatial' čo metodologické východisko autoriek 
predpokladá sociálne ukotvenú identitu. Preto sa dá pochopit', prečo v prvej kapitole autorky tvrdia, že filozofická teória človeka by mala odrážat' reálny vzt'ah človeka $\mathrm{k}$ svetu, a to v ontologickej, existenčnej forme. To však nepochybne znamená, ako naznačujú samy autorky, že treba nadviazat' na pokusy vyrovnat' sa s naturalizmom a redukcionizmom (prehodnotit' vzt'ah človeka k vlastnému telu) a teóriami o l'udskej prirodzenosti (l'udská prirodzenost' ako tabula rasa, ako stelesnenie prírodného ušlachtilého divocha alebo ducha v stroji (s. 23).

Druhá čast' publikácie obhajuje tézu, že univerzálne deklarovanie l'udských práv bez akéhokol'vek sociálneho a politického kontextu je skôr len ideologickým konštruktom, ktorý sa inštrumentálne, najmä v rovine medzinárodného práva, zneuživa a využiva. Autorky možný prameň zneužívania idey l'udských práv vidia v tom, ako sa pracuje s prívlastkami l'udských práv - s kategóriami neodňatel'nosti, neodcudzitel'nosti, nepremlčatel'nosti, nezrušitel'nosti. Tieto prívlastky deklarujú bezčasovost', univerzálnost', všeobecnú platnost' l'udských práv, akoby suplovali božie desatoro s ich normatívnou autoritou (s. 26). Navyše treba poznamenat', že ide o prirodzeno-právny slovník z 18. storočia. Preto by sa ludské práva nemali chápat' ako predpisy, vzory, ktoré sa majú nasilu aplikovat' v konkrétnych spoločenských pomeroch. Avšak ich ukotvenie a uplatňovanie by sa malo interpretovat' $v$ konkrétnom inštitucionálnom zázemí a spoločensko-politickom konsenze, pretože každý človek je primárne začlenený do nejakého politického systému, ktorý ho napokon ako adresáta právnych nárokov aj rešpektuje (s. 32). Z tohto prístupu vyvodzujú aj konkrétne konzekvencie pre praktické opatrenia, ktoré by mali vychádzat' zo sociálno-konštrukcionistického definovania postihnutia (vrátane fyzických aj psychických poškodení a deficitov) (s. 41), čo je zrejmé aj z úvah o deinštitucionalizácii sociálnych služieb na Slovensku (s. 119 - 129). Tento interpretačný rámec je pre autorky ústredným východiskom skúmania l'udských práv v kontexte zdravotného postihnutia, čím poskytujú istý druh predstavy o tom, aký charakter má zdravotné postihnutie a čo špecifikuje osoby so zdravotným postihnutím.

Tretia kapitola publikácie sa zameriava na interpretačné problémy Dohovoru OSN o právach osôb so zdravotným postihnutím, ktorý spolu s Opčným protokolom k Dohovoru OSN o právach osôb so zdravotným postihnutím podpísal prezident Slovenskej republiky dňa 26. septembra 2007. Autorky si pritom všímajú najmä problém rovnosti a nediskriminácie, definície zdravotného postihnutia či práva na nezávislý život. Aj v tomto prípade zdôrazňujú sociálny model chápania zdravotného postihnutia, čo ich do istej miery limituje voči prípadným námietkam, ktoré boli vznesené vo vzt’ahu k tomuto modelu. Autorky rovnost' a právo v oblasti l'udských práv považujú za potenciálny prostriedok na dosiahnutie spoločenských zmien potrebných na odstránenie sociálnych bariér (s. 51 - 52), čo niektorí môžu označit' za utopickú predstavu o zmysluplnej sociálnej zmene. Autorky sa taktiež zaoberajú problémom práva 
na nezávislý život, pričom zdôrazňujú, že článok 19 odkazuje na právo na život v spoločenstve, no nie je dostatočný na vymedzenie práva na nezávislý spôsob života, pretože právo na nezávislý život je ovel’a širšie - závisí od faktorov daných prostredím a človekom (s. 61).

Ďalšia kapitola je venovaná analýze pojmu zdravotné postihnutie z hl’adiska rôznych prístupov. Táto kapitola zohráva $\mathrm{v}$ rámci publikácie dôležitú úlohu, pretože prostredníctvom nej možno reflektovat' výrazové prostriedky nárokov a povinností, ktoré sa vzt'ahujú k osobám so zdravotným postihnutím, a taktiež výber pojmov a výrazov, ktorými sa vypovedá o zdravotnom postihnutí. Autorky približujú tri relevantné modely zdravotného postihnutia, pričom značnú čast' venujú východiskám prístupov, ktoré sú zamerané na sociálne fungovanie - na model spôsobilostí podla Amartya Sena. Jeho základným východiskom je kvalita l'udského života v jeho pluralitných podobách. Ludské blaho konceptualizuje prostredníctvom pojmov fungovanie (functioning) a spôsobilosti (capabilities) (s. 75). V tomto modeli diagnóza zdravotného postihnutia nezávisí primárne od biomedicínskej tradície, a ani od modelu ICF (International Classification of Functioning), ale od merania funkčností a spôsobilostí jednotlivca v konkrétnom sociálnom kontexte. Toto môže viest' ku kritickej pozícií - napokon tú autorky aj pripúšt’ajú (s. 81) -, podl'a ktorej meranie rozsahu poškodenia je náročné a nejednoznačné, pretože závisí od konkrétneho kontextu funkčných dôsledkov. Napriek tomu sa autorky pokúšajú ukázat', že model A. Sena možno implementovat' do praxe, ako sa o to pokúsila aj nemecká ekonómka $W$. Kuklysová. Navyše kladú osobitný dôraz na výhody a limity implementácie tohto modelu v našom prostredí, čo môže byt' podnetné najmä pri úvahách o tom, čo treba realizovat', aby osoby so zdravotným postihnutím mali súbor základných materiálnych podmienok potrebných na život hodný l'udskej dôstojnosti.

V predposlednej kapitole autorky analyzujú úlohu autonómnej subjektivity vo vzt’ahu k osobám so zdravotným postihnutím. Autonómia je v súčasnej filozofii dôležitý koncept, a to aj so zretel'om na aplikovanú etiku, pretože pokial' ide o isté druhy zdravotného postihnutia (napr. duševného charakteru), uvažuje sa o vymedzení rozsahu princípu rešpektovania autonómie. Dôvodom týchto úvah je skutočnost', že napríklad zdravotnícki pracovníci a ich pacienti nemusia zdielat' rovnaké systémy hodnôt, čo podnecuje otázku, či a do akej miery má byt' obmedzená subjektívna autonómia pri rozhodovaní o liečebnom režime. Autorky tento problém reflektujú rozvíjaním kritiky vo vzt’ahu $\mathrm{k}$ tradičnej autonómii liberálneho individualizmu, $\mathrm{v}$ ktorej subjektívna autonómia Kantovho racionálne sa rozhodujúceho subjektu nedokáže zahrnút' subjekty s obmedzenými schopnostami rozhodovat' za seba. Navyše takýto prístup abstrahuje od sociálnej povahy človeka (s. 95). Ako alternatívu predkladajú koncept intersubjektívne konštituovanej identity (relational autonomy). Zástancovia tohto prístupu sú presvedčení, že autonómia je vždy formovaná aj vzt’ahmi k druhým (s. 89). Z tohto 
pohl'adu autonómia tkvie $\mathrm{v}$ súbore sociálne nadobudnutých praktických kompetencií v oblasti sebadôvery, sebaúcty, sebaocenenia, sebapoznávania a sebaurčenia (s. 99). Výhodou tohto prístupu je odkazovanie aj na sociálny kontext - rôzne formy socializácie môžu ul'ahčit' alebo bránit' rozvoju autonómie, a preto otázka, či je alebo nie je vol'ba jednotlivca slobodná, musí byt' určená odkazom na sociálny kontext. V tomto zmysle autorky v tretej kapitole interpretujú aj koncepciu tzv. podporovaného rozhodovania (supported decision making) (s. 58). Autorky sa síce explicitne nevyjadrujú k možnostiam a limitom tohto druhu uvažovania o autonómii na praktickej úrovni, no v zásade predostierajú intelektuálne skromné stanovisko, podl’a ktorého tieto úvahy z filozofického hl'adiska môžu byt' podnetom pre hl'adanie nových vízií, a to najmä v kontexte oslabovania medzigeneračných väzieb, solidarity a sociálnej kohézie (s. 106).

Posledná kapitola je zameraná na právo osôb so zdravotným postihnutím na nezávislý život a právo na integráciu a začlenenie do spoločnosti. Sústred’uje sa na analýzu praktických problémov súvisiacich s ich uplatňovaním v našom prostredí. Autorky v nej poukazujú na nejednoznačné definovanie inštitucionálnej starostlivosti (s. 110), ale upozorňujú aj na negatívne konzekvencie právnej úpravy v oblasti sociálnych služieb (s. 113 - 116).

Rozpracovanie filozofických prístupov v kontexte l’udských práv osôb so zdravotným postihnutím má vel'ký metodologický význam a teoreticko-praktický dosah na spoločenské vedy - sociológiu, etiku, estetiku, pedagogiku a iné, pretože otvára priestor pre pochopenie rôznych foriem filozofických zdôvodnení l'udských práv. Na záver treba vyzdvihnút' snahu autoriek vysporiadat' sa s explicitne naturalistickými koncepciami chápania zdravotného postihnutia, autonómie, zmyslu života či nezávislosti. Celkovo monografiu možno hodnotit' ako podnetný príspevok $\mathrm{k}$ objasneniu tejto problematiky. Prístup autoriek k riešeniu otázky l'udských práv v kontexte zdravotného postihnutia považujeme za vel'mi perspektívny, pretože môže pomôct' odkryt' iné možnosti riešenia a perspektívy uplatňovania l'udských práv osôb so zdravotným postihnutím v praxi. Monografiu možno odporúčat' nielen akademickej, ale aj širšej verejnosti, ktorej osud spoluobčanov so zdravotným postihnutím nie je l'ahostajný.

Martin Foltin

Martin Foltin

Filozofický ústav SAV

Klemensova 19

81364 Bratislava 1

Slovenská republika

e-mail: mart.foltin@gmail.com 